\title{
Reform of Creditor Participation Procedures in Municipal Bankruptcy
}

New York City's financial crisis ${ }^{1}$ has prompted concern about the viability of the federal municipal bankruptcy act (Chapter IX). ${ }^{2}$ Chapter IX was enacted during the Depression to control the rash of defaults by small towns and improvement districts ${ }^{3}$ and was not designed to accommodate problems of the scale posed by New York and other major cities." Since the other chapters of the Bankruptcy Act are expressly inapplicable to municipalities, ${ }^{5}$ creditors of large cities ${ }^{\mathfrak{b}}$ may

1. New York City nearly defaulted on the repayment of its bonded debt in October, 1975. City officials predicted that a default in December was inevitable in the absence of federal aid. N.Y. Times, Oct. 19, 1975, $\$ 4$, at 1, col. 1. On December 6, 1975, Congress approved a $\$ 2.3$ billion loan to the city. Id., Dec. 7, 1975, at 1, col. 8. For discussions of the financial crisis, sec $i d$., Aug. 30, 1975, $\$ 4$, at 1 , col. 3; id., Sept. 28, 1975, $\$ 4$, at 14, col. 1; id., Oct. 18, 1975, at 1, col. 8; Newswerk, Sept. 15, 1975, at 27-28; Business WeEk, Sept. 1, 1975, at 51, 53.

2. 11 U.S.C. $\$ \$ 401-403$ (1970). Because of New York's financial problems, "all eycs turned to Chapter IX. . . [It] has little utility and cannot be used in circumstances similar to those faced by New York." King, Municipal Insolvency: Chapter IX, Old and New; Chapter IX Rules, 50 AM. BANkr. L.J. 55, 56 (1976).

3. Between 1929 and $1937,4,771$ governmental units defaulted on repayment of their indebtedness. Of these, there were 417 counties, 1,434 incorporated municipalities, 88 towns and organized townships, 1,241 school districts, 944 reclamation, levee, irrigation, and drainage districts, 646 other special districts, and one state. G. HemPel, The Postwir Quility of State and Local Debt 22 (1971). As of March 1, 1934, 95 percent of the cities and towns in default had populations under 30,000. A. Hillhouse, Municipat Bonds: A Century of EXPERIENCE 22 (1936).

For further statistical information on defaults, both before and after the Bankruptcy Act, see J. Maxwel., Financing State and Local Governments 179-85 (1965); A. Rabinowitz, MUnicipar. Bond Finance and Administration (1969); Shanks, The Extent of Municipal Defaults, 24 Nat'L MuN. REV. 32 (1935).

4. In the hearings on the predecessor to Chapter IX, the Mayor of Detroit argued that the bill the committee eventually reported was useful only to small cities. Hearings on H.R. 1670, 3083, 4311, 5267, and 5009 before the House Comm. on the Judiciary, 73d Cong., 1st Sess. 84-87 (1933) (statement of Frank Murphy).

For general surveys of the Municipal Bankruptcy Act and its history, see Lehman, The Federal Municipal Bankruptcy Act, 5 J. FinsN. 241 (1960); Patterson, Municipal Debt Adjustments Under the Bankruptcy Act, 90 U. PA. L. Rev. 520 (1942); Note, $A$ Survey of Municipal Bankruptcy Law and Procedure, 38 Brooklyn L. REv. 478 (1971); Note, The New Federal Municipal Debt Re-Adjustment Act, 24 VA. L. REv. 181 (1937). The statute is also discussed in 5 CoLLICR on B.ANKRUPTCY ff f81.01-81.27 (14th ed. 1974) [hereinafter cited as Collier]; 2 Modern Bankruptcy Manual: Law And Practice $\$ \$ 1411-1441$ (1966); 10 H. ReMington, BankruptcY LAW $\$ \$ 4284-4344$ (rev, ed. 1947).

5. 11 U.S.C. $\$ 22(a)(1970)$.

6. The revision of Chapter IX recently proposed by President Ford applied only to cities with populations of one million or more. Wall St. J., Oct. 30, 1975, at 27, col. 4 . This Note rejects a definition of "large city" based only on population. Instead, it will define a large city simply as one where the size and structure of the debt prevent the use of existing federal bankruptcy procedures. See note 61 infra. 
be left to the uncertain state remedies that Congress intended to bypass. ${ }^{7}$

Perhaps the most flawed provision of Chapter IX is the requirement that a plan of municipal debt readjustment be approved by a vote of the creditors. The revisions of Chapter IX recently proposed by the Senate and House of Representatives ${ }^{8}$ do not remedy the inadequacy. This Note proposes an alternative procedure for creditor participation in municipal bankruptcy. ${ }^{9}$

7. When Chapter IX was enacted, it was assumed that the contracts clause of the Constitution, U.S. CoNST. art. I, $\S 10$, cl. 1, precluded any scaling down or extension of municipal debts by the states. Ashton v. Cameron County Water Improvement Dist. No. One, 298 U.S. 513, 531 (1936). See Hearings on H.R. 2505, 2506, 5403, and 5969 Before the Subcomm. on Bankruptcy and Reorganization of the House Judiciary Comm., 75th Cong., lst Sess. ser. 3, at 123 (1937) (statement of Rep. J. Mark Wilcox). In Faitoute Iron \& Steel Co. v. City of Asbury Park, 316 U.S. 502 (1942), however, the Court held that a state could enact laws providing for compositions of indebtedness. Congress responded with an amendment to the municipal bankruptcy act specifying that no state law establishing a method of composition could be made binding on nonconsenting creditors. Act of July 1, 1946, ch. 532, $\$ 83,60$ Stat. 409 (codified at 11 U.S.C. $\$ 403(i)$ (1970)). Since it is generally not permissible to execute on the property of a municipality except as provided by statute, 30 AMr. JUR. 2D Executions $\$ \$ 195-99$ (1967), the only available state remedy is mandamus to compel levy of taxes. Yet the ineffectiveness of this remedy had prompted passage of Chapter IX in the first place. Hearings on H.R. 1670, 3083, 4311, 5267, and 5009, supra note 4, at 24-25 (1933) (statement of Rep. J. Mark Wilcox). For discussion of the shortcomings of state remedies, see Dimock, Legal Problems of Financially Embarrassed Municipalities, 22 VA. I.. REv. 39 (1935); Fordham, Methods of Enforcing Satisfaction of Obligations of Public Corporations, 33 Colum. L. REv. 28 (1933); Frye, Municipal Insolvency: Its Special Problems from the Point of View of the General Practitioner, 2 Legal, Notes on LoGal Gov't 195 (1937).

However, a state may not be powerless to extend municipal debts. A moratorium on New York City's bonded debt has been enacted by the New York State legislature and upheld as constitutional by the state supreme court. Flushing Nat'l Bank v. Municipal Assistance Corp., N.X.L.J., Dec. 24, 1975, at 6, col. 2 (Sup. Ct. Spec. Term, Dec. 23, 1975).

8. In December, 1975, the House of Representatives passed H.R. 10624, 94th Cong., Ist Sess. (1975) [hereinafter cited as H.R. 10624], a revision of Chapter IX. The Senate adopted a similar measure, S. 2597, 94th Cong., 1st Sess. (1975) [hereinafter cited as S. 2597]. The differences between the two bills were reconciled by a conference committec on February 20, 1976. Wall St. J., Feb. 23, 1976, at 4, col. 3.

The House and Senate bills represent a synthesis of a number of prior proposals. The recommendations of the Commission on the Bankruptcy Laws of the United States are embodied in Chapter VIII of H.R. 31, 94th Cong., 1st Sess. (1975) (the Senate counterpart is S. 236, 94th Cong., Ist Sess. (1975)). Those of the National Conference of Bankruptcy Judges are embodied in Chapter IX of H.R. 32, 94th Cong., 1st Sess. (1975) (the Senate counterpart is S. 235, 94th Cong., 1st Sess. (1975)). On October 29, 1975, President Ford proposed a similar revision, N.Y. Times, Oct. 30, 1975, at 48, col. 1; Wall St. J., Oct. 30, 1975, at 3, col. 1. On September 30, 1975, Congressman Herman Badillo introduced H.R. 9926, 94th Cong., 1st Sess. (1975), proposing abolition of the creditor approval provisions of Chapter IX. The rules proposed by the Judicial Conference would accomplish within the present statutory structure some of the reforms in these bills. CoMm. oN Rules of Practice and Procedure, Judicial Conf. of the U.S., Preliminary Drift of Proposed Rulrs UNder Chapter IX of the Bankruptcy Act (July 1974).

This Note will focus on the revisions adopted by the Senate and the House of Representatives.

9. Other troublesome aspects of Chapter IX addressed by the House and Senate revisions but not discussed in this Note include the treatment of executory contracts, sec H.R. 10624, $\$ \$ 82(\mathrm{~b}), 88(\mathrm{c})$; S. $2597, \$ \S 801$ (b)(1), $\$ 10(\mathrm{~b})$, the arrangement of priorities, sec 


\section{The Creditor Approval Provisions}

Chapter IX provides for composition of indebtedness ${ }^{10}$ by a city or other local governmental agency ${ }^{11}$ which is insolvent or unable to meet its debts as they mature. ${ }^{12}$ The city may invoke the jurisdiction of the bankruptcy court by filing a petition alleging insolvency. ${ }^{13} \mathrm{~A}$ plan of composition approved in writing by or on behalf of creditors holding at least 51 percent by value of the securities ${ }^{14}$ affected by the plan must accompany the petition. ${ }^{15}$ The plan then becomes the subject of hearings at which all creditors may present objections and suggest alternatives. ${ }^{13}$ The court may approve modifications in the plan, subject to

H.R. 10624, $\$ 89 ;$ S. $2597, \S 812$, and the issuance of certificates of indebtedness, see H.R. 10624, $\S 82(\mathrm{~b})(2) ; \mathrm{S}$. $2597, \S 811$. For a brief discussion of these provisions, see King, supra note 2 , at $61-64$.

10. A composition is an agreement between an insolvent debtor and its creditors to scale down the former's obligations. Under the federal bankruptcy power, U.S. Const. art. I, $\$ 8$, cl. 4, an agreement accepted by a statutorily prescribed majority of creditors may be imposed by the court on the minority. See Cumberland Glass Co. v. DeWitt, 237 U.S. 447,452 (1915).

Before enactment of Chapter IX, only voluntary compositions of municipal debts werc possible, requiring unanimous creditor approval of the plan of repayment. This requirement allowed a small minority of creditors to frustrate any rearrangement of debts and encouraged pressure tactics by the majority. Some of the problems that arose are catalogued in Dession, Municipal Debt Adjustment and the Supreme Court, 46 YALE L.J. 199 (1936). One purpose of Chapter IX is to bind all creditors to a plan approved by twothirds of them and found equitable by the court. See In re Drainage Dist. No. 7, 25 F. Supp. 372, 377 (E.D. Ark.), aff'd, 104 F.2d 696 (8th Cir.), cert. denied sub nom. Haverstick v. Drainage Dist. No. 7, 308 U.S. 604 (1939).

11. Governmental units that may petition under Chapter IX include various irrigation, reclamation, and local improvement districts, as well as municipalities and counties. 11 U.S.C. $\$ 401$ (1970). This Note will consider only the application of the statute to municipalities. For a discussion of its application to the other governmental units, see Note, A Survey of Municipal Bankruptcy Law and Procedure, supra note 4.

12. Il U.S.C. $\$ 403$ (a) (1970). For a discussion of standards for determining whether a city is insolvent, sce 5 Collier, supia note 4 , \ 81.05 , at $1565-66$ n.2.

13. 11 U.S.C. $\$ 403(a)(1970)$. The city's participation is entirely voluntary. It must file the initial petition and approve the final plan. Moreover, the statute disavows any attempt to impair the control of the state over municipalities, including control over expenditures. Id. $\$ 403$ (i).

14. In addition to bonds and notes, "securities" could include claims for wage, pension, and welfare payments. See pp. 428-29 \& note 37 infra.

15. II U.S.C. $\$ 403$ (a) (1970). The rules for Chapter IX proposed by the Judicial Conference would eliminate the 51 percent requirement. CoMm. ON Rules of Practice AND Procedure, supra note 8, Rule 9-24 (1974). The authority conferred on the Judicial Conference, however, is to propose procedural changes to the Supreme Court for its consideration and adoption, modification, or rejection, "in accordance with law." 28 U.S.C. $\$ 331(1970)$. It would seem that the proposed procedural changes have encroached on the substance of the statute in violation of the Conference's mandate.

Along with the petition, the city must file a list of all known creditors. 11 U.S.C. $\$ 403(a)$ (1970). The proposed rules interpret this provision as requiring a list of claims, including bearer bonds whose holders are unknown. Comm. on Rules of Practice and Procedure, supra Rule 9-7.

16. 11 U.S.C. $\$ 403$ (b) (1970). Although the statute does not explicitly give the creditor a right to present objections in person as well as in writing, the requirement that notice of the time and place of hearings be sent to all creditors, id. $\$ 403(\mathrm{~b})$, indicates that op- 
the right of creditors adversely affected by the changes to withdraw their initial approval. ${ }^{17}$

To be confirmed by the court, the final plan must be accepted in writing by or on behalf of creditors holding two-thirds of all claims allowed. ${ }^{1 s}$ The judge also must find that the arrangement is "fair, equitable, and for the best interests of creditors and does not discriminate unfairly in favor of any creditors or class of creditors." 19 Under certain limited circumstances, the court may disregard an unfavorable vote and impose a plan that the creditors have rejected. ${ }^{20}$

The proposed revisions of Chapter IX eliminate the requirement that an approved plan accompany the petition."1 Both bills also reduce the requirement for final confirmation to acceptance by creditors

portunity for personal appearance is contemplated.

Creditors may be represented by a protective committee in all phases of Chapter IX proceedings. Such a committee must file with the court a list of names and addresses of all the creditors whom it represents, as well as a complete description of their securities and a signed contract with each authorizing the committee to operate as his agent. Id. \$ 403(a).

17. Id. $\S 403(\mathrm{e})$.

18. Id. $\$ 403(d)$. In Mason v. Paradise Irrigation Dist., 326 U.S. 536, 544 (1946), the Court construed this provision to require acceptance by "two-thirds of the total amount of all claims of all classes." There has been some confusion about how to calculate the total debt of the municipality. Some courts apparently have included all the debt, regardless of whether creditors have filed claims, in determining whether the requisite percentage of approval has been reached. See Clark, Procedures Under Act for Composition of Indebtedness of Local Taxing Agencies, 20 ORE. L. Rev. 316, 320 (1941). But sce Equitable Reserve Ass'n v. Dardanelle School Dist., 138 F.2d 236, 237-39 (8th Cir. 1943). In that case, the district court, in determining what percentage of creditors had approved the plan, included creditors who had not filed claims. The Eighth Circuit appears not to have included them nor to have realized that its method of calculation differed from that of the district court. Rule 9-22 of the proposed rules for Chapter IX, Comm. on Rules of Practice and Procenure, supra note 8, would resolve this confusion by allowing all claims on the city's list not designated as disputed, contingent, or unliquidated.

19. 11 U.S.C. $\S 403(\mathrm{e})(1970)$.

20. This prerogative is referred to as the "cramdown power." The statute provides that the court need not secure the assent of any creditor or class of creditors if the plan does not materially affect them, if it provides for payment of their claims in cash or in full, or if it ensures "the protection of the interests, claims, or lien of such creditors or class of creditors." Id. $\$ 403$ (d). The proposed revisions retain this provision. H.R. 10624, \$ 92(d); S. 2597, \$ 814(a). The cramdown power in Chapter IX has never been exercised, $10 \mathrm{H}$. Rfmington, supra note $4, \S 4327$, at 570 , and therefore it is difficult to ascertain whether the provision in the current and proposed statutes presents the court with a viable alternative to elimination of the creditor vote. The adequacy of the protection required for exercise of the power is determined by reference to the value of the creditors' claims, which depends on future tax revenues. See Kelley v. Everglades Drainage Dist., 319 U.S. 415, 420 (1943). The greater the range of forecasts of future revenues, the greater the court's discretion under the cramdown provisions. However, the cramdown provisions allow the court to circumvent or override a creditor vote without requiring that all creditor interests be represented in the formulation and confirmation of the plan. $C f$. pp. 433-34 infra.

21. H.R. 10624, § 90(a); S. 2597, § 813(b). See H. REP. No. 94-686, 94th Cong., list Sess. 6-7 (1975) [hereinafter cited as House REPORT]; S. REr. No. 94-458, 94th Cong., 1st Sess. 14 (1975) [hereinafter cited as Senate RePoRT]. 
holding two-thirds in amount of the claims in each class that are voted. ${ }^{22}$ The Senate revision adds the requirement that 51 percent of the creditors voting in each class accept the plan. ${ }^{23}$ If any one class of creditors rejects the final plan, the court must find that the plan adequately protects the creditors' interests and use its cramdown power, ${ }^{24}$ or the petitioner must modify the plan to make it acceptable to the court or the creditors. ${ }^{25}$ If such a modification adversely affects the interests of any creditors, they may withdraw their acceptance.26 As in the current statute, the court has the option of rejecting a plan that does not meet the statutory standards. ${ }^{27}$

\section{Problems with the Creditor Approval Provisions}

\section{A. Objections to the Existing Chapter IX Provisions}

Chapter IX proceedings are designed to give the force of law to a voluntary agreement worked out between the city and its creditors. For many cities, however, this design is likely to prove unworkable. Both the initial 51 percent and the subsequent $66-2 / 3$ percent creditor approval provisions are formidable barriers to using federal bankruptcy procedures. ${ }^{2 s}$

The size and structure of the municipal securities market make it extremely difficult to obtain the approval of municipal bond- and noteholders. ${ }^{20}$ Unlike corporate debentures, many municipal bonds

22. H.R. 10624, $\$ \$ 92($ b) , (c); S. $2597, \S 814$ (a).

23. S. $2597, \S 814(\mathrm{a})$. The conference version of the bill retains the requirement of approval by a numerical majority of creditors. Telephone interview with Richard Levin, Ass't Counsel, House Subcomm. on Civil and Constitutional Rights, Feb. 24, 1976.

24. H.R. 10624, \$ 92(d); S. 2597, \$ 814(a).

25. H.R. 10624, \$ 90(b); S. $2597, \$ 815$.

26. H.R. 10624, \$ 92(c); S. $2597, \S 815$.

27. Both the House and Senate bills change slightly the language of the existing law. The Senate resision requires that the plan be found "fair, equitable, feasible, and not unfairly discriminatory in favor of any creditor or class of creditors." S. 2597, $\$ 817$ (c)(1). Compare p. 426 supra. The House bill uses similar language. H.R. 10624, $\$ 94(\mathrm{~b})(\mathrm{l})$. The Senate revision also requires that it appear from current and projected revenues and expenditures that the city's budget will be in balance within a reasonable time after adoption of the plan. S. 2597, $\$ 817$ (c)(7).

28. The creditor approval provisions were less of a problem for small cities in DCpression-era Chapter IX proceedings. The Reconstruction Finance Corporation often would buy a large portion of the outstanding bonds directly from the holders at the proposed composition rate and vote the bonds in favor of the plan. HOUSE REPORT, supra note 21 , at 7.

29. King, supra note 2, at 56. As of June 30, 1974, New York City had bonded debt of over Sill billion, 2 Moody's Municipal \& Gov't Maxual 2527 (1975), and Los Angeles had bonded debt of 51.8 billion, 1 id. at 416. As of December 31, 1973, Chicago's debt was $\$ 0.9$ billion, $1 \mathrm{id}$. at 1023 , and Houston's was $\$ 0.6$ billion, 2 id. at 3365 ; as of June 30,1973 , Detroit's was $\$ 0.7$ billion, 1 id. at 1710 . 
and notes are unregistered, made out simply to "bearer."'io Furthermore, while commercial banks and institutions hold large numbers of these obligations, individuals also hold a substantial proportion. ${ }^{31}$ Simply contacting the necessary percentage of these creditors would thus appear impossible..$^{32}$

Moreover, bond- and noteholders are not the only creditors of the city whose consent is required. Under Chapter IX, a "creditor" is one who holds securities, defined broadly as "bonds, notes, judgments, claims, and demands, liquidated or unliquidated, and other evidences of indebtedness, secured or unsecured, and certificates of benefical interest in property." 33 This definition should be liberally construed in order to facilitate settlement of all the city's obligations and to subject all settlements to the scrutiny of the court. ${ }^{34}$ The history of the statute indicates that salary and wage claimants qualify as creditors. $^{35}$ In addition, welfare recipients would have a claim against the

30. King, supra note 2, at 56; Securities Industry Assoctation, Fundamentals of MuNICIPAL Bonds 6 (9th ed. 1973). For a further description of the municipal bond market, see E. Davis, “. . . Of the People By the People for the Peorle . . ." (rev, ed. 1958; A. RABINowitz, stepra note 3 .

31. At the end of 1973 , commercial and mutual savings banks held 50.8 percent of the obligations of state and local governments, and households held 26.5 percent. The balance of the debt was held by insurance companies, state and local governments, and business corporations. See BoArd of Governors of the Federal Reserve System, Flow of Funds Accounts 1965-1973, at 42 (Supp. 1974).

It has been estimated that 160,000 individuals or families currently hold $\$ 4.89$ billion in New York City bonds, about two-thirds of the $\$ 7.35$ billion in outstanding bonds. N.Y. Times, Oct. 19, 1975, at 48, col. 2. Senator William Proxmire, Chairman of the Senate Banking Committee, put the figure at 180,000 in suggesting the impossibility of obtaining a "uniform response" from such a large number of creditors. Id., Oct. 26, 1975, at 56, col. 5 .

32. In the recent financial crisis, New York City officials claimed they could not identify a sufficient number of creditors to meet the statutory requirement for 51 percent approval. N.Y. Times, Oct. 30, 1975, at 48, col. 1; id., Oct. 5, 1975, at 51, col. 2; id., Aug. $30,1975, \S 4$, at 1 , col. 3 .

33. 11 U.S.C. $\$ 402$ (1970). See, e.g., Poinsett Lumber \& Mfg. Co. v. Drainage Dist. No. 7, 119 F.2d 270 (8th Cir. 1941) (landowner's unadjudicated claim for damages caused by water orerflow in construction of a floodway by the district made him a creditor within the meaning of the municipal bankruptcy statute).

34. In a case under Chapter $X$ of the Bankruptcy Act, 11 U.S.C. $\$ \$ 501-676$ (1970), the Seventh Circuit stated that the holder of "any character of claim against the debtor or its property" should be treated as a creditor and that "a broad construction should be given to the statute with respect to claims and creditors in order to dispose of all liabilities of the debtor in reorganization ...." In re Plankinton Bldg. Co., 135 F.2d 273, 275 (7th Cir. 1943) (allowing bondholders who had not exchanged their securities for those of the successor corporation in a previous reorganization to be treated as creditors of the successor corporation). See 6 Collier, supra note 4, 1 2.05 (broad interpretations of Chapter X definition of creditor). The term "creditor" should also be broadly construcd under Chapter IX.

35. See Note, The New Federal Municipal Debt Re-Adjustment Act, supra note 4, at 186. The first municipal bankruptcy statute specifically excluded salary and wage claimants. Act of May 24, 1934, ch. 345, $\$ 80,48$ Stat. 798, 799. The existing law does not contain that exclusion.

Claims for back pay clearly would fit under the statutory definition. Breach of a collective bargaining agrecment or other employment contract would give rise to a claim for 
city if it failed to fulfill its statutory obligation to pay benefits. ${ }^{36}$ Trade creditors and beneficiaries under municipal pension funds would also fall within the statutory definition.

If a city's plan of reorganization affected these creditors, ${ }^{37}$ their approval would be necessary. While there would be no problem in identifying them, it is questionable whether a percentage sufficient to fulfill the statutory requirement would vote. ${ }^{38}$ And, as is the case with bond- and noteholders, a large number of individuals would be involved. ${ }^{39}$

Assuming a sufficient percentage of creditors could be contacted and encouraged to vote, logistical problems in conducting the vote itself would delay and complicate the readjustment proceeding. The creditor protective committees which made earlier proceedings manageable ${ }^{40}$ are likely to be ineffective or nonexistent for many classes of creditors. ${ }^{41}$

damages. Under certain circumstances, city employees who were laid off might have a claim for the deprivation of their "property interest" in continued employment. See Perry v. Sindermann, 408 U.S. 593, 599 (1972); Board of Regents of State Colleges v. Roth, 408 U.S. 564, $571-72$ (1972).

36. See, e.g., N.Y. Soc. SERv. LAW $\$ \S 158,349$ (eligibility); $\$ \$ 61,62,153,348$ (city responsibility) (McKinney Supp. 1974). The welfare recipient's statutory entitlement to benefits might also be considered a property right which the recipient could claim had been violated by a failure to pay benefits. See Goldberg v. Kelly, 397 U.S. 254, 262 n.8 (1970).

37. Judge Simon Rifkind, testifying before the Senate Banking Committee, predicted that "without question" New York would be unable to pay employees in the event of default. N.Y. Times, Oct. 11, 1975, at 39, col. 1. Nor would there likely be enough funds to pay welfare recipients. Wall St. J., Oct. 24, 1975, at 34, col. 5. Further, in New York, a reduction of pension burdens would be a necesary part of any readjustment of debts. N.Y. Times, Oct. 26, 1975, at 56, col. 3. It would seem therefore that at least in New York, these classes of creditors would have to be included in any plan.

38. The likelihood that a given individual will vote depends in part on his perceived ability to influence the outcome of the election. Cf. A. Downs, An Economic Theory of DEMOCRicy 36-50 (1957). In the face of large concentrations of debt in commercial institutions and unions, many individual creditors might consider their influence too slight to warrant voting.

39. Salary and wage claimants represent a substantial number of potential creditors. As of February, 1972, New York City had 439,396 employees. U.S. Buread of the Census, County And City DATA Book, 1972, at 564 (1973). Los Angeles had 220,882 employees; Chicago, 190,562; and Detroit, 120,928. Id. at 554-55.

Welfare recipients also would constitute a large class of potential claimants. In New York City, 1,126,231 individuals received either Aid to Families with Dependent Children or Old Age Assistance in 1972, id. at 572; in Los Angeles, 757,204, id. at 562; in Chicago, 537,713, id. at 552; and in Detroit, 299,115, id.

40. The committce can act in all capacitics authorized by the creditor. It may receive notice on behalf of the individual creditor and cast the votes of its constituents as a block. See 5 Coll.IER, supra note 4, ๆ 81.09; 11 U.S.C. $\$ 403$ (d) (1970) (acceptance of plan by or on behalf of creditors).

41. The requirement that the committee have written authorization from each creditor it purports to represent will lead to the same types of logistical difficulties that voting requirements raise. See pp. 427-28 supra. Yet this requirement cannot be relaxed if the committee system is to be used. Abolition of the written authorization requirement is fundamentally different from abolition of the creditor vote, proposed in Part III infra. The latter would increase the power of the court; the former would increase the power and decrease the accountability of private individuals. 
In the absence of committees, creditors must receive individual notice before each vote and be given a reasonable period to respond. Since many of these creditors may be unable to evaluate the plan without professional advice, the court probably would have to allot substantial time for a response. ${ }^{42}$ When the creditors do respond, the court will face the time-consuming task of classifying claims ${ }^{43}$ and tabulating votes. ${ }^{44}$ After all of these efforts, the court could reject the entire plan as inequitable, necessitating dismissal of the proceedings. ${ }^{45}$

\section{B. Objections to the House and Senate Revisions of Chapter IX}

In order to facilitate access to the bankruptcy court and bring negotiation of a plan under the court's jurisdiction, the House and Senate revisions of Chapter IX abolish the initial creditor consent requirement. ${ }^{46}$ However, the proposed statutes do not indicate how the court should exercise this jurisdiction to ensure a fair plan. ${ }^{47}$ This failure to provide supervision is troublesome in the case of large cities.

When small towns and taxing districts sought relief under the Bankruptcy Act, local officials could meet informally with representatives of substantially all the creditors and work out a plan.8s The number of creditors of a large city, their widely divergent interests, and the incomplete network of creditor committees preclude such informality. The practical limitations of the ad hoc bargaining process might engender difficult questions as to whom the court should include in the negotiations. A desire for fairness would dictate representa-

42. The House RePORT, supra note 21 , at 29 , observes:

The court should consider such factors as the time it will take to transmit the plan to all who are entitled to receive a copy, and the time within which it is reasonable to expect that a creditor can examine the plan and make an informed decision.

43. 11 U.S.C. $\$ 403$ (b) (1970). The judge must classify creditors according to the funds from which repayment is made, according to priority in repayment, and according to the nature of their claims and interests. 5 Collier, supra note 4, If 81.15 .

44. 11 U.S.C. $\$ 403$ (d) (1970).

45. $I d . \S 403(\mathrm{e})$.

46. See House Reporr, supra note 21, at 6; H.R. 10624, $\$ 90(a)$; S. 2597, $\$ 813(a)$; cf. REPORT OF THE COMMISSION ON THE BANKRUPTCY LAwS OF THE UNITED STATES (pt. I), 93d Cong., Ist Sess. 274 (1973) (arguing that the 51 percent requirement should be eliminated because it pressures the judge to confirm the plan by presenting him with a fait accompli).

47. Indeed, the House Report, supra note 21, at 10, observes: "Because of the flexibility of the process under the Bankruptcy Act, there is no limit to the nature of negotiation that the petitioner may undertake ...."

The first municipal bankruptcy act was also criticized for limiting the court's jurisdiction orer negotiations. Douglas, The Legal Problem of Control Over Protective Commitlees for Municipal and Quasi-Municipal Obligations, 2 LEgAL Notes oN Loc.IL Gov'r 81, 85 (1936).

48. Cf. C. Chatters \& A. Hillhouse, Locil Government Debt Administration 307, 341-42 (1939). 
tion of all interests in the formulation of the plan, but every creditor conceivably could claim a distinct interest requiring that he be included.

To circumvent the problem of locating and organizing creditors for the final vote, the proposed revisions reduce the requisite approval to two-thirds of those voting in each class. ${ }^{49}$ The Senate provision requires in addition a numerical majority of creditors voting in each class. ${ }^{50}$ These modifications leave many problems unresolved. The revisions do not avoid the logistical difficulties in providing notice to and conducting a vote of perhaps millions of creditors. Indeed, the provision for a class-by-class vote increases the chances that the initial plan will not be accepted. If either the creditors or the court reject the plan, the logistical problems of the creditor approval process would have to be confronted anew.

As a matter of statutory policy, ${ }^{, 1}$ the expense and delay of requiring approval by a percentage of claims voted could be justified if outweighed by an increased likelihood of obtaining a plan fair to all the creditors. ${ }^{\text {ge }}$ But such a requirement would decrease, rather than increase, the chances for a fair plan. Many creditors will not vote, and the nonvoters will not be distributed randomly among all types and classes of creditors. Almost all institutional investors and creditor protective committees presumably will vote; many individual investors, welfare recipients, and nonunionized employees presumably will not. ${ }^{.3}$ Hence the revisions may place approval of a plan of readjustment in the hands of "banks, brokerage houses, and other large creditors." If the court does not classify creditors according to amount of holdings or degree of organization, ${ }^{\mathrm{J} \breve{z}}$ the requirement that every class approve

49. H.R. $10624, \S 92(b)$, (c); S. 2597, \$ 814(a).

50. S. $2597, \$ 814(\mathrm{a})$.

51. For the argument that the creditor vote is not constitutionally required, sec pp. $435-38$ infra.

52. Cf. R. Posner, Economic Axalysis of Law 333 (1973).

53. Under the existing requirement of approval by a percentage of all claims against the debtor, 11 U.S.C. $\$ 403(\mathrm{~d})(1970)$, a failure to rote is in effect a vote against the plan. Substituting a requirement of approval by a percentage of claims voted would give those opposed to the plan an incentive to vote, but would decrease the incentive to vote of those in favor of the plan. The substitution would also decrease the voting incentive of small, unorganized creditors, whether for or against the plan. Given the difficulties of locating these creditors, a lower percentage of their claims will be roted than claims of institutional and organized creditors. The proposal for approval by percentage of claims voted therefore increases the influence of the latter group of creditors. The small creditor perceiving this imbalance may think his vote even less important.

54. Statment by Rep. Herman Badillo, Sept. 30, 1975, at 1 (press release) (on file with Yale Law Journal).

55. While the House bill provides more flexible classification standards than the existing law, the standards relate to the characteristics of the claims rather than to the characteristics of the creditors. House RePORT, supra note 21, at 11. The House REPORT, supra at 27, cited In re Hudson-Ross, Inc., 175 F. Supp. 111, 112 (N.D. Ill. 1959), in which 
the plan (subject to the judge's cramdown power) ${ }^{\text {si }}$ would not eliminate the danger of domination by larger and better organized creditors. A judge relying on the creditor vote as conclusive proof of the fairness of the plan-as some judges apparently have done under Chapter IX ${ }^{51}$-may confirm a plan that is in fact unfair to the interests of smaller or less organized creditors.

The Senate requirement of approval by numerical majority may mitigate these difficulties, but does not resolve them. Although the provision was added to "balance the power" of large creditors, ${ }^{58}$ it cannot fully counteract the effect of their higher turnout rate. ${ }^{59}$ More importantly, it gives an advantage to creditors who can organize over those who cannot (e.g., union over nonunion labor).

Even if most creditors voted, the creditor approval provisions borrowed from the reorganization sections ${ }^{60}$ still would not fulfill their function. The reorganization chapters assume that creditors have sufficient financial sophistication to protect their business interests and that a substantial percentage of those creditors will organize protective committees with access to more specialized financial expertise. In a municipal debt readjustment, these assumptions are questionable. Municipal creditors include many groups who may be unable to evaluate the plan without assistance. Yet the creditors most in need of financial advice may be those least able to organize protective committees. $^{61}$ The purpose of a vote is to allow the creditor the

the district court held that 10 principal creditors who had agreed to extension of the debtor's obligations could not properly be treated as a separate class. Moreover, the House bill made the exception that unsecured creditors holding claims of less than \$100 may be a separate class, H.R. $10624, \S 88(\mathrm{~b})$, suggesting that the judge would not otherwise have the power to classify creditors on the basis of amount of claims held.

56. H.R. 10624, § 92(d); S. 2597, § 814(a).

57. See, e.g., Wells Fargo Bank \& Union Trust Co. v. Imperial Irrigation Dist., 136 F.2d 539, 550 (9th Cir. 1943), cert. denied, 321 U.S. 787 (1944); In re Drainage Dist. No. 2, 28 F. Supp. 84, 85 (D. Idaho 1939). See also Foster, Conflicting Ideals for Reorganiza-

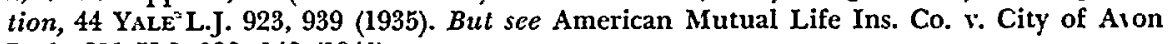
Park, 311 U.S. 138, 148 (1940).

58. Senate Report, supra note 21 , at 21 .

59. To the extent the Senate provision alleviates the perceived disparity of influence between large and small creditors, it may increase the incentive of the latter to vote. See notes 38,53 supra.

60. 11 U.S.C. $\$ \$ 205(e), 579$ (1970). See H.R. REP. No. 207, 73d Cong., 1st Sess. (1933) (House Report on predecessor to Chapter IX). The revisions appear largely to incorporate the creditor approval provisions recommended by the Commission on the Bankruptcy Laws of the United States, which specifically correlates the creditor approval provisions for municipal bankruptcy with those for corporate reorganization. REPORT OF THE CoMMission ON The BankRurtcy Laws of The UNited States (pt. II), supra note 46, at 268.

61. Moreover, municipal bondholders may not have the same access to expertise through protective committees as do corporate bondholders. The requirement that protective committees have written authorization from every creditor they purport to represent would makc it difficult to form committees to represent holders of bearer bonds. 
opportunity to express his opinion on whether the plan adequately protects his interests. If he has no idea how the plan affects his claim, his vote is meaningless.

\section{An Alternative Procedure for Creditor Participation}

These shortcomings dictate elimination of the creditor approval provisions and design of alternative provisions for creditor participation. This Note proposes an alternative which entails a two-stage debt readjustment scheme. The city would initiate the first stage by filing a petition alleging insolvency ${ }^{62}$ and requesting that the court institute the creditor participation procedures outlined below. Should the court find that the existing or revised creditor approval provisions hinder the orderly readjustment of debts, ${ }^{63}$ it would grant the city's request, order notice of the proceedings to formulate a plan, and appoint a panel of trustees to hear the creditors. ${ }^{64}$ The number of trustees and the size of their staff should be sufficient to develop a plan within the time designated by the court. ${ }^{65}$

At the inception of the hearings, the panel of trustees would decide whether the various creditor protective committees should be recognized $^{B 6}$ and whether they may appear at the subsequent confirmation hearing before the court. The panel would also choose representatives to appear at the confirmation hearing on behalf of classes of creditors without protective committees. ${ }^{67}$ Any creditor could come before the panel to present views on an acceptable plan of debt readjustment and to challenge the adequacy of his representative. ${ }^{68}$ After the hearings,

62. As under the House and Senate revisions, the filing of the petition would operate as a stay of creditor suits. H.R. 10624, $\$ 85($ c); S. $2597, \S 805$.

63. The creditor approval provisions may be kept in the circumstances where they were intended to apply: where substantially all of the creditors of the city or their representatives can vote on a plan without unreasonable cost or delay. This question would be within the discretion of the court, guided by such criteria as the size of the city, the amount of the debt, and the types of creditors.

64. Like Chapter X trustees, the panel would formulate the plan of reorganization, see 11 U.S.C. $\$ 569$ (1970), and would have to be "disinterested," see id. $\$ \S 556,558$. But unlike their Chapter $X$ counterparts, they would not assume control of the debtor. See id. $\$ 589$.

65. Each trustee could hear a different class or type of creditor and allow each creditor to present views orally or to file a written statement. With the creditors thus allocated among a number of trustees, the proceedings should take less time than under the existing procedures. Sec Newsweek, Sept. 15, 1975, at 27; Statement of Rep. Badillo, supra note 54, at 1 (estimating two to three years for New York to meet the initial creditor consent requirement).

66. See 11 U.S.C. $\$ 403(a)$ (1970) (requirements for protective committees under Chapter IX).

67. The representatives could participate in the proceclings before the panel if the trustees found themselves unable to discern the interests of the class after hearing those individual creditors who chose to speak.

68. Existing Chapter IX, the House and Senate revisions, and the other reorganization statutes allow all creditors to be heard at confirmation hearings. See, e.g., 11 U.S.C. 
the panel would negotiate for the creditors with appropriate city officials to formulate a plan. ${ }^{69}$ The city would participate as an equal partner in the bargaining process; neither the panel nor the judge could impose a plan on the city, dictate its fiscal policy, or assume control of its operations. ${ }^{70}$

The second stage of the proceedings would be the confirmation hearings on the plan. At the hearings, the court first would review the panel's choice of representatives and appoint others for those interests which remained inadequately represented. Only creditor representatives approved by the court would have standing at the confirmation hearings. With the consent of the city, the court could either modify the plan to meet statutory criteria or remand to the panel if major changes were required. The court would only confirm a plan meeting statutory standards. ${ }^{71}$

\section{Advantages of the Proposed Procedures}

Elimination of the creditor approval provisions and adoption of the above proposal would solve many of the deficiencies of the existing statute and the proposed revisions. The proposal allows the court to bypass the difficulties in securing the consent of a prescribed percentage of creditors. It also insulates the confirmation hearings from a barrage of objections from individual creditors. ${ }^{72}$

$\$ 403$ (b) (1970) (Chapter IX); id. $\$ 606$ (Chapter X). The judicial hearing under the procedures proposed in this Note is granted only to creditor representatives. However, the creditor would be allowed to appear at the confirmation hearing if he could show that his representative was inadequate under the standard of FED. R. CIv. P. 24(a)(2), providing for intervention as of right. A representative is inadequate if he has acted in bad faith, if he possesses or represents an interest adverse to the creditor's, or if he is guilty of nonfeasance in his duty of representation. See 3B Moore's Federal. Practice i 24.08(2), at 24.18-85 (2d ed. 1975) [hereinafter cited as MOORE]. The creditor's right of intervention may be "subject to appropriate conditions or restrictions responsive among other things to the requirements of efficient conduct of the proceedings." Notes of Advisory Committee on 1966 Amendment to Rules, 28 U.S.C. app. at 7771 (1970).

69. To ensure good faith performance of the trustees' duties to the creditors, a record of the negotiations should be made for review by the court.

70. Even if these restrictions are not required by the Tenth Amendment, sec note sl infra, they are justificd by limitations on judicial competence. The judiciary is not equipped to perform the administrative and legislative functions involved in running a city. Furthermore, it is undesirable to take control from the elected city officials and give it to court appointees.

71. See 11 U.S.C. $\$ 403(\mathrm{e})(1970)$. For a discussion of the "fair and equitable" standard under Chapter IX, see p. 439 infra.

72. The existing statute and the proposed revisions confer standing on all creditors to object to the plan, 11 U.S.C. $\$ 403$ (b) (1970); H.R. 10624, $\$ 93 ;$ S. 2597, $\$ 816$, but require the judge to conduct these hearings. Indeed, the revisions narrowly limit the reference of factual questions to a referee or spccial master. H.R. 10624, $\$ 87(\mathrm{a})$; S. 2597, $\$ 822(a)$. In the absence of institutional arrangements to accommodate the considerable number of individual creditors seeking to be heard, the court could be inundated and a readjustment of debts delayed. 
Such a reform also would mitigate the logistical problems of the present statute and the proposed revisions. Instead of eight rounds of notice as presently required, ${ }^{73}$ creditors would receive notice only twice ${ }^{74}$-at the beginning of the proceedings and after confirmation, when the securities must be surrendered. ${ }^{i 5}$ Other time-consuming tasks, such as classifying claims and hearing the views of creditors, still must be performed, but are delegated to the panel of trustees to avoid burdening the court and delaying the proceeding. Under these alternative procedures, the court still could reject a plan as inequitable. Yet formulation and confirmation of a new plan would not necessitate a new proceeding and a new vote, ${ }^{76}$ nor would the panel have to seek creditor approval for every modification of the plan.

Another advantage of the proposal is that, unlike the existing statute or the proposed revisions, which allow a vote only after the plan has been drawn up, it guarantees creditors a right to participate in the formulation of the plan. In addition, all creditor interests will be represented throughout the proceedings. This representation provides more balanced creditor participation than a vote skewed toward well-organized groups of creditors.

\section{Problems Created by the Proposal}

\section{A. Constitutional Considerations}

Legislation concerning municipal debt readjustment is within the express power of Congress to "establish uniform Laws on the subject of Bankruptcies throughout the United States." 7 t Placing the statute

73. The Judicial Conference's proposed Rule 9-14 for Chapter IX notes the steps in the proceeding where notice is required under existing law. Comm. on Rules of Practice ANd Procedure, supra note 8.

74. Creditors desiring to appear before the panel would also receive notice of the time and place of their hearing before the panel. Only the creditor representatives need to receive notice of the confirmation hearing, since only they would appear.

75. Under the House and Senate revisions, creditors would also receive notice before each vote and after each modification. H.R. 10624, $\$ \$ 90(b), 92(e) ;$ S. 2597, $\$ \S 807,815$. The House bill would require the creditor, upon receipt of initial notice, to request the additional notice provided under existing Chapter IX. H.R. 10624, \$ 85(d). The Senate bill would permit but not require the judge to adopt this procedure for notice upon request. S. $2597, \$ 807(d)$.

76. Under the existing statute, 11 U.S.C. $\$ 403(c)(1970)$, and the Senate bill, S. 2597, $\$ 817(\mathrm{c})$, the proceedings must be dismissed if the judge rejects the plan as not meeting the statutory standards. Under the House bill, a new plan may be proposed if the court grants more time to do so. H,R. 10624, $\$ 98(4)$.

77. U.S. CoNst. art. I, $\$ 8, \mathrm{cl}$. 4. The "subject of bankruptcies" is "nothing less than the subject of the relations betwcen an insolvent or non-paying or fraudulent debtor, and his creditors, extending to his and their relief." Continental Ill. Nat'l Bank \& Trust Co. v. Chicago, R.I. \& Pac. Ry., 294 U.S. 648, 672-73 (1935); United States v. Bekins, 304 U.S. 27, 47 (1938). 
within the power, however, does not remove it from the purview of other constitutional provisions. ${ }^{78}$ In Ashton v. Cameron County Water Improvement District No. One, ${ }^{79}$ the Supreme Court held that the predecessor to Chapter IX interfered with state control of municipal government in violation of the Tenth Amendment, but two years later, after cosmetic changes by Congress, the Court in United States v. Bekins upheld what is now Chapter IX.80

While the Tenth Amendment no longer presents a serious constitutional problem, ${ }^{\text {s1 }}$ Fifth Amendment objections to the proposal of this Note may seem more substantial. The Bekins Court rejected a Fifth Amendment challenge by relying on cases which upheld compositions under other federal bankruptcy statutes. ${ }^{82}$ The proposal eliminates the creditor vote-the crucial element in the composition; the question is whether this departure from the traditional model for

78. See Kuehner v. Irving Trust Co., 299 U.S. 445, 451 (1937); Louisville Joint Stock Land Bank v. Radford, 295 U.S. 555,589 (1985).

79. 298 U.S. 513 (1936).

80. 304 U.S. 27 (1938). It is difficult to reconcile Bekins and Ashton. The Bekins Court quoted the conclusion of the House Report that the new statute was constitutional because it permitted no interference with the "fiscal or governmental affairs" of political subdivisions of the state. 304 U.S. at 51, quoting H. REP. No, 517, 75th Cong., 1st Sess. 2.4 (1937). However, the first act expressly prohibited judicial interference with state or municipal government. Compare Act of May 24, 1934, ch. 345, $\$ 80$ (c)(11), (k), 48 Stat. $798,801,802$, with 11 U.S.C. $\$ 403$ (c), (i) (1970). Intending to reduce the impingement on state and local sovereignty, Congress eliminated some minor provisions of the first act (e.g., the application of the statute to counties, the requirement that a taxing district open its books to creditors, and the authorization for rejection of exccutory contracts by the city). It is hard to see constitutional significance in these changes.

One commentator has suggested that the revised statute was upheld because it provided for a composition. Patterson, supra note 4, at 525, 528. Yet so did the first statute in effect, if not in terms: a plan approred by the prescribed majority of creditors was imposed on the minority. See note 10 supra.

81. The Court has upheld federal laws under the commerce power even where they intruded substantially on state interests. Northwestern Elec. Co. v. FPG, 321 U.S. 119 (1944); Troppy v. La Sara Farmers Gin Co., 113 F.2d 350 (5th Cir. 1940). In Maryland v. Wirtz, 392 U.S. 183, 195 (1968) (Fair Labor Standards Act held applicable to state employees), the Court stated: "[T] he Federal Government, when acting within a delegalcul power, may override countervailing state interests whether these be described as "governmental' or 'proprietary' in character." (Emphasis added.) An exercise of the delegated bankruptcy power should be as immune from Tenth Amendment attack as an exercise of the commerce power.

82. The Court stated without claboration, 304 U.S. at 54:

As the bankruptcy power may be exerted to give effect to a plan for the composition of the debts of an insolvent debtor, we find no merit in appellant's objections under the Fifth Amendment,

and cited In re Reiman, 20 F. Cas. 490 (No. 11,673) (S.D.N.Y. 1874) (upholding constitutionality of Bankruptcy Act of 1869); Continental IIl. Nat'l Bank \& Trust Co. v. Chicago, R.I. \& Pac. Ry., 294 U.S. 648 (1935) (upholding constitutionality of $\$ 77$, the railroad reorganization statute). See Getz v. Edinburg Consol. Independent School Dist., 101 F.2d 734, 736 (5th Cir.), cert. dismissed, 308 U.S. 628 (1939) (Fifth Amendment challenge to municipal bankruptcy act rejected on ground that composition was effected by agreement of majority of creditors); see also Louisville Joint Stock Land Bank v. Radford, 295 U.S. 555, 585-86 (1995). 
relief of the insolvent debtor undermines the constitutionality of the statute.

The mere absence of a vote does not render the readjustment of debts a taking of private property without just compensation or a deprivation of property without due process of law. ${ }^{83}$ The traditional composition permits a plan to be imposed on a dissenting minority of creditors; the cramdown power permits a plan to be imposed on a dissenting majority, "so long as the creditor gets all the value of his lien and his share of any free assets." ${ }^{4}$ The crucial requirement is that the court find the plan fair and equitable. Where the court so finds, eliminating the vote altogether seems no more objectionable than overruling a negative vote. ${ }^{85}$

The proposal also should withstand any procedural due process objections. Every creditor will receive the minimum procedural safeguards of notice and an opportunity to be heard before the panel of trustees. ${ }^{\mathrm{si}}$ In addition, every creditor will be represented before the court at the confirmation hearing. ${ }^{.7}$ Although the existing municipal

S3. U.S. Consr. amend. $V$ provides:

[N]or shall any person ... be deprived of life, liberty, or property, without due process of law; nor shall private property be taken for public use, without just compensation.

84. Reconstruction Fin. Corp. v. Denver \& R.G.W.R.R., 328 U.S. 495, 533 (1946) (footnote omitted) (upholding cramdown power under $\$ 77$ of the Bankruptcy Act, 11 U.S.C. $\$ 205(e)(1970)$ ). For a discussion of the cramdown power under Chapter IX, see note 20 supra.

85. In the Regional Rail Reorganization Act Cases, 419 U.S. 102 (1974), upholding the constitutionality of the Regional Rail Reorganization Act, 45 U.S.C. $\$ \$ 701-93$ (Supp. IV 1974), the Supreme Court recently went further in allowing Congress to dispense with creditor approval provisions in bankruptcy legislation. The Rail Act requires the reorganization trustees of certain Northeast railroads to convey rail properties to a newly created private corporation without a prior judicial determination that the plan for compensating the creditors of the railroads is fair and equitable and without submission of the plan to a vote by the creditors. See id. $\$ \$ 717,719,743$. Citing Reconstruction Fin. Corp. v. Denver \& R.G.W.R.R., 328 U.S, 495 (1946), see note 84 supra, the Court rejected constitutional challenges to the mandatory conveyance, on the ground that creditors would be able to sue in the Court of Claims under the Tucker Act, 28 U.S.C. \$ 1491 (1970), for any amount by which their compensation fell short of the constitutional minimum. 419 U.S. at 148-56. See Note, Convail and Liquidation Value: Creditors' and Stockholder' Entitlement in the Regional Rail Reorganization, 85 YALE L.J. 371, 377-80 \& n.21 (1976). Of course, no Tucker Act remedy would be necessary under the municipal bankruptcy procedures proposed here, because the court would not confirm a plan it did not find fair and equitable.

86. "The fundamental requisite of due process of law is the opportunity to be heard." Grannis v. Ordean, 234 U.S. 385, 394 (1914); Bell v. Burson, 402 U.S. 535, 542 (1971); Goldberg v. Kelly, 397 U.S. 254, 267 (1970).

87. The limited right of intervention in class actions in the federal courts suggests that adcquate representation in itself satisfies the requirements of due process. If federal bankruptcy remedies were not arailable, creditors could bring a class action against a debtor under Fed. R. Civ. P. 23(b)(1). See 3B Moore, supra note 68, If 23.35[2], at 23-604 (1975). Indeed, since a municipal bankruptcy proceeding requires the consent of the municipal dcbtor, see 11 U.S.C. $\$ 403(\mathrm{a})(1970)$, there may still be a role for the creditor class suit when the city is unwilling to enter bankruptcy. See 3B Moore, supra \23.09, 
bankruptcy and corporate and railroad reorganization statutes give every creditor the right to vote on the plan and to be heard at the confirmation hearing, the rights granted in equity receiverships, from which these statutes evolved, were more limited. ${ }^{88}$ The statutory procedures are not necessary to satisfy the requirements of due process of law. The process which is due depends on a balancing of the government's interest in expediting the proceeding and the individual's interest in the outcome. ${ }^{89}$ Giving every creditor a vote on the plan and a right to be heard at the confirmation hearing could threaten the financial viability of a large city-and perhaps even its ability to govern itself ${ }^{90}$-by impeding the readjustment of its debts. The government's interest in a manageable readjustment of municipal debts outweighs the interest of the creditor in further participation in the proceeding. ${ }^{91}$

at 23-2571 n.l, citing Women's Catholic Order of Foresters v. City of Ennis, 116 F.2d 270 (5th Cir. 1940), cert. denied, 313 U.S. 589 (1941) (creditor who did not receive notice could not challenge result of bondholders' class suit against city in default). In a (b)(1) class action, the creditor would be bound by the outcome even though unable to opt out of the class, see FED. R. Civ. P. 23(c)(2); 3B MOORE, supra fi 23.11[2], at 23-2826, and would have no right to intervene in the proceeding if the party conducting the litigation could adequately represent the creditor's interest. FED. R. Civ. P. 24(a)(2). Providing the creditor with a remedy under the bankruptcy statutes does not increase the level of procedural protection required by the Constitution. Nevertheless, the rights afforded under the proposal are more substantial than those granted in federal class actions because every creditor would receive notice and an opportunity to be heard at the first stage of the proceedings.

88. See II U.S.C. $\$ 205(\mathrm{c})(13)$, (e) (1970) (railroad reorganization); id. $\$ 403(\mathrm{~b})$, (d) (municipal bankruptcy); id. $\$ \$ 579,606$ (corporate reorganization).

In equity receivership, the procedures discouraged individual participation. S.E.C. Report on the Study and Investigation of the Work, Activities, Personnel, and Functions of Protective and Reorginizition Committees (pt. VIII) 191 (1940). Stockholders were held to be adequately represented by directors and officers of the corporation; creditors, by the receiver; bondholders, by the indenture trustee. Only in the event of fraud or collusion would the courts find such representation inadequate and permit individuals to intervene. $3 \mathrm{~B}$ Moore, supra note 68 , If 24.11[1.-1].

89. Cafeteria \& Restaurant Workers Union v. McElroy, 367 U.S. 886, 895 (1961); Goldberg v. Kelly, 397 U.S. 254, 263-66 (1970); Arnett v. Kennedy, 416 U.S. 134, 168-7I (1974) (Powell, J., concurring).

90. In the absence of a federal bankruptcy statute, a state court could issue mandamus to compel the city in default to levy taxes to pay judgment creditors. See note 7 supra. Default of a large city might also lead to the appointment of a federal or state trustce to oversee the fiscal operations of the city. Cf. Act of June 10, 1975, ch. 168, 169, [1975] Sess. Laws of N.Y. (McKinney) (establishing the Municipal Assistance Corporation).

91. In the Regional Rail Reorganization Act Cases, 419 U.S. 102, 156 (1974), the Supreme Court rejected a procedural due process challenge to a mandatory conveyance of rail properties in a federally subsidized reorganization even though the reorganization court was to order conveyance before it reviewed the adequacy of the compensation paid to creditors. See note 85 supra. The Court noted on the one hand that creditors were assured fair compensation because they could sue in the Court of Claims for any shortfall, and on the other hand that

the procedural sequence is vital to accomplishing the goals of the Act. If judicial review of the terms of the transfer was required before the conveyance could occur, the conveyance might well come too late to resolve the rail transportation crisis. 419 U.S. at 156. 


\section{B. Ensuring a Fair Plan}

Although constitutional, these alternative procedures for creditor participation might be criticized on grounds of policy as less likely to result in a fair plan than procedures which retain the creditor vote. The plan negotiated by the panel of trustees with the city might be more favorable to the city than a plan subject to creditor approval. The lack of accountability to the creditors might increase the trustees' temptation to collude with the city or at least decrease their incentive to advance energetically the interests of the creditors. These dangers would be lessened by judicial enforcement of the trustees' duty to represent the interests of the creditors and by judicial review of the record of the negotiations between the trustees and the city. ${ }^{92}$ Ultimately, the creditors' interests would be protected by strict application of the statutory requirement that the plan be "fair, equitable, and for the best interests of the creditors." ${ }^{3}$ Under Chapter IX, courts have interpreted this standard to require that the plan provide the creditors with all the revenues the city can raise by the exercise of its taxing power without impairing government functions. ${ }^{9 *}$ The fairness of the plan to the creditors would be ensured by insisting that their compensation reflect the maximum ability of the debtor to pay.

92. See note 69 supra.

93. 11 U.S.C. $\$ 403($ e) $(1970)$. This phrase is a term of art, invoking the absolute priority rule:

[E] ach class of creditors is to be awarded, in order of its priority, as much of the going-concern value of the enterprise as is necessary to pay it off in full before the next class may receive any participation, and no class may accept less than the amount to which its priority entitles it if assets are distributed to a more junior class. Brudney, The Bankruptcy Commission's Proposed "Modification" of the Absolute Priority" Rule, 48 Am. BANkr. L.J. 305, 307-08 (1974). See Blum \& Kaplan, The Absolute Priority Doctrine in Corporate Reorganization, 41 U. ChI. L. REv. 651, 652 (1974).

The absolute priority rule applies in Chapter IX proceedings. 5 CoLlier, supra note 4, ff 81.19, at 1585-86 n.6, citing Kelley v. Everglades Drainage Dist., 319 U.S. 415 (1943). See $10 \mathrm{H}$. ReMINGToN, supra note $4, \$ 4317$, at 554 .

94. $10 \mathrm{H}$. Renrngton, supra note $4, \$ \$ 4317,4322$. To meet this requirement, the city must raise taxes to the statutory or cconomic limit, the cconomic limit being the tax rate at which the highest revenues can be obtained. In Fano v. Newport Heights Irrigation Dist., 114 F.2d 563, 565-66 (9th Cir. 1940), the court stated:

[W] are unable to find ... why it can be said that the plan is "equitable" and "fair" and for the "best interests of creditors" with no sufficient showing that the taxing power was inadequate to raise the taxes to pay them.

This same standard is imposed by the threshold requirement that the city be "insolvent or unable to meet its debts as they mature." 11 U.S.C. $\$ 403(a)(1970)$. Thus, in Ouerbacker v. Henderson County, 126 F.2d 309, 313 (4th Cir. 1942), a finding of insolvency was upheld where an increase in taxes would have decreased revenues.

That the city must use the full measure of its taxing power does not mean that it must allocate all its revenues to payment of its debt. It may retain sufficient funds to provide essential governmental services. See Getz v. Edinburg Consol. Independent School Dist., 10I F.2d 731, 736 (5th Cir.), cert. dismissed, 308 U.S. 628 (1939) (where primary purpose of the insolvent school district was to provide facilities for education, 50 percent of its tax revenues was properly directed toward that end). 
One might argue that the creditor vote is important as a check not only on the trustees' formulation of the plan but also on the court's discretion in determining whether the plan is fair and equitable. But the thesis advanced here has been that a vote dominated by large and well-organized municipal creditors does not provide a guarantee or even a reliable indication of the fairness of the plan.

It is thus essential that Congress eliminate the creditor approval provisions and enact procedures for creditor participation which permit a manageable readjustment of the debts of large cities. If it fails to enact such reform, Congress will leave the municipal bankruptcy act ineffectual where most needed. 